\title{
The effective application of international human rights law standards to the sporting domain: Should UN monitoring bodies take central stage?
}

\author{
Carmen Pérez González ${ }^{1}$ (D)
}

Accepted: 23 December 2021 / Published online: 10 February 2022

(c) The Author(s) 2022

\begin{abstract}
This work aims to reflect on the role that UN human rights monitoring bodies—both charter and treaty based—could play in tackling human rights violations of athletes rights occurred in the sporting domain. While recognizing the autonomy of sports associations in the application of their own lex sportiva, the author maintains that the perspective and concrete recommendations provided by UN human rights mechanisms could help (i) raise human rights standards applied by sporting associations and (ii) more effectively combat discriminatory and other harmful or unfair practices in sport. Thus, the purpose of the analysis is twofold. First, the work will examine the reasons behind the absence of a significant UN human rights mechanisms/bodies practice so far. Secondly, it will support that autonomy of sport should not imply that athletes could be prevented from having access to these mechanisms seeking concrete recommendations regarding changes in situations of discrimination or application of such harmful or unfair practices. While identifying certain obstacles to individual access, the work advocates for a more decisive action of these mechanisms in this regard. In particular, through Committees' General Recommendations and Concluding Observations, on the one hand, and special procedures of the Human Rights Council's pronouncements, on the other.
\end{abstract}

Keywords International Human Rights Law standards · UN human rights monitoring bodies · Human right to sport · Human rights violations of athletes $\cdot$ Autonomy of sport $\cdot$ Lex sportiva

\section{Introduction}

'States individually are the primary duty-bearers under international human rights law, and collectively they are the trustees of the international human rights regime,

\footnotetext{
${ }^{1}$ UNCHR (2011) Guiding Principles on Business and Human Rights. Implementing the United Nations "Protect, Respect and Remedy" Framework, available at https://www.ohchr.org/documents/publi cations/guidingprinciplesbusinesshr_en.pdf (accessed 27 August 2021).
}

\section{Warming up: about the multidimensional relationship between sport and international human rights law}

The analysis of the relationship between sports and international human rights law (IHRL) admits a triple approach. First, there is a growing consensus on the idea of conceiving sport as a useful tool for the promotion of human rights worldwide. In this regard, it seems undeniable that the inarguable allure of sport has pushed states and International Organizations to resort to it as a means of fostering the protection and promotion of human rights (Kirchschlaeger 2017, p. 337). This link has been otherwise explicitly reclaimed

Carmen Pérez González

carmen.perez@uc3m.es

1 Universidad Carlos III de Madrid, Madrid, Spain 
by the Unites Nations General Assembly (UNGA). ${ }^{2}$ On this subject, sport has also been labelled by the United Nations (UN) Secretary General as 'a global accelerator for peace and sustainable development for all' in a Report adopted in September 2020. ${ }^{3}$ It also provides some very illustrative examples in this respect. It refers for instance to the sport, cultural diplomacy and recreational houses initiatives of Colombia that 'promote social inclusion, peaceful coexistence, and intercultural dialogue in the groups that are most vulnerable to forced recruitment of minors. The initiative fights the recruitment and use of minors by illegal armed groups and guarantees the development of children through sports, cultural and educational activities' ${ }^{4}$ In a similar vein, it highlights the work of Italy in 'promoting social inclusion through sport by involving amateur sports associations and societies, voluntary organizations, associations and social promotion cooperatives in the development of sporting projects. The projects encourage civic and social values and the combatting of exclusion and discrimination by promoting the integration of persons with disabilities, ethnic minorities, immigrants and vulnerable social groups'. ${ }^{5}$ Sport has also been expressly considered in the UN 2030 Agenda for Sustainable Development. ${ }^{6}$ Finally, the idea of sport being a useful vehicle for the advancement of human rights has been developed in connection with the notion of sports diplomacy (Jarvei 2021, Murray 2013).

Second, questions can be raised about the legal recognition of (the practice of/access to) sport as a human right. Such a right has been incorporated in soft law instruments specific of public international law. Without a doubt, the most relevant one is the International Charter on physical education and sport, adopted on 21 November of 1978 by the UNESCO General Conference and revised in November $2015 .^{7}$ In the framework of IHRL, the question of the

\footnotetext{
${ }^{2}$ Resolution $65 / 4$ of 18 October 2010 on sport as a means to promote education, health, development and peace (A/RES/65/4) emphasizes and encourages the use of sport as a vehicle to empower girls and women. The Resolution is available at https://undocs.org/en/A/RES/ 65/4 (accessed 27 August 2021).

3 A/75/155/Rev.1, available at https://digitallibrary.un.org/record/ 3894270 (accessed 27 August 2021).

${ }^{4}$ Ibidem, at paragraph 53.

5 Ibidem, at paragraph 68.

${ }^{6}$ UNGA Resolution of 25 September 2015, A /RES/70/1, available at https://www.un.org/ga/search/view_doc.asp?symbol=A/RES/70/ $1 \&$ Lang $=\mathrm{E}$ (accessed 27 August 2021). The Resolution recognizes 'the growing contribution of sport to the realization of development and peace in its promotion of tolerance and respect and the contributions it makes to the empowerment of women and of young people, individuals and communities as well as to health, education and social inclusion objectives' (at 37).

7 Available at https://unesdoc.unesco.org/ark:/48223/pf0000235409 (accessed 27 August 2021). Art. 1 of the Charter establishes that the practice of physical education, physical activity and sport is a human right for all.
}

establishment of a human right to sport/physical activity/ education has been addressed from different angles. Firstly, that right has been conceived as part of the right to education, particularly in the case of minors,${ }^{8}$ and as part of the right to health. ${ }^{9}$ Secondly, a wide range of human rights treaties address the question in relation to non-discrimination of certain vulnerable groups. Regarding women, the Convention on the elimination of all forms of discrimination against women (CEDAW Convention) plays a pivotal role. ${ }^{10}$ Both articles $10 . g$ ) and 13.c), expressly mentioning sport and physical activity, are particularly clear in connection with this point. At the European level, article 14.2 of the Council of Europe 2011 Convention on preventing and combating violence against women and domestic violence is also relevant. ${ }^{11}$ Article 5 of the Convention on the elimination of all forms of racial discrimination ${ }^{12}$ and article 30 of the Convention on the rights of persons with disabilities ${ }^{13}$ should also be mentioned. Thirdly, cases of non/or inadequate access to physical or sporting activities have been considered, under certain circumstances, an inhuman or degrading treatment. Examples of this can be found within pronouncements of both $\mathrm{UN}^{14}$ and Council

\footnotetext{
${ }^{8}$ See art. 29.1.a) of the Convention on the rights of the child (available at http://www.ohchr.org/EN/ProfessionalInterest/Pages/CRC.aspx) (accessed 27 August 2021).

${ }^{9}$ See art. 12.1 of the International Covenant on economic, social and cultural rights (available at http://www.ohchr.org/EN/Profession alInterest/Pages/CESCR.aspx accessed 27 August 2021) and Human Rights Council (HRC) Resolution 26/18 on the right of everyone to the enjoyment of the highest attainable standard of physical and mental health: sport and healthy lifestyles as contributing factors, available at http://www.ohchr.org/EN/Issues/Health/Pages/OverviewMa ndate.aspx (accessed 27 August 2021).

${ }^{10}$ CEDAW Convention was adopted on 18 December 1979 and entered into force on 3 September 1981, in accordance with art. 27.1. At the time of writing, 189 states are parties to it. It is available at http://www.ohchr.org/EN/ProfessionalInterest/Pages/CEDAW.aspx (accessed 27 August 2021).

11 The Convention is available at https://www.coe.int/en/web/conve ntions/full-list/-/conventions/treaty/210 (accessed 27 August 2021). This article refers to education in some issues, such equality between women and men, non-stereotyped gender roles, and mutual respect. It obliges states parties to include teaching materials on these questions both in formal curricula and in informal educational facilities, as well as in sports, cultural and leisure facilities and the media'. Emphasis added.

12 Adopted on 21 December 1965 and entered into force on 4 January 1969. It is available at https://www.ohchr.org/en/professionalint erest/pages/cerd.aspx (accessed 27 August 2021).

13 Adopted on 13 December 2006 and entered into force on 3 May 2008. It is available at https://www.ohchr.org/en/hrbodies/crpd/pages/ conventionrightspersonswithdisabilities.aspx (accessed 27 August 2021).

${ }^{14}$ See for instance paragraph 5.h) of the Concluding Observations the Committee Against Torture to the third periodic report of Bulgaria (CAT/C/CR/32/6) adopted in June 2004, available at http://
} 
of Europe ${ }^{15}$ human rights monitoring bodies. Despite this, more or less serious discrimination in access to sport prevails in a number of states. Perhaps the most obvious is the recently announced Taliban government's ban on women playing sport in public in Afghanistan. Of course, it is not the only example. Cases of state bans on women playing certain sports have been repeated throughout history. ${ }^{16}$

Finally, the question of how to tackle human rights abuses in the sporting domain has drawn considerable attention from both scholars and practitioners. Although allegations about human rights abuses in connection with sports organizations' activities are not new, they have been usually overshadowed. With self-regulation being a traditional claim of the sport movement, national and supranational institutions have met with serious difficulties when intervening in the sector. Sport governing bodies (SGB's) have traditionally called both for independence and normative and organizational autonomy. The sport movement tends to apply its own set of rules and procedures, its own lex sportive, that has been be defined 'as the body of sports law generated by the sports movement and generally applied by CAS' (Parrish 2012, p. 716). In this context, it seems obvious why national and international courts and human rights monitoring bodies have only intervened in a limited way in cases relating sports disputes.

It could be affirmed that this situation is coming to an end to give a step to a renovated relationship between lex sportiva and IHRL. Different pieces of evidence would support this conclusion. First, certain recent events reveal the growing interest of sports associations on human rights enforcement. ${ }^{17}$ Second, athletes seem prepared to challenge the compatibility of sporting rules with IHLR before

\footnotetext{
Footnote 14 (Continued)

www.ohchr.org/EN/HRBodies/CAT/pages/catindex.aspx (accessed 27 August 2021).

15 The European Committee for the Prevention of Torture (CPT) has repeatedly affirmed that persons deprived of liberty should have daily access to the practice of physical activity or sport: See CPT Standards on 'Living space per prisoner in prison establishments' (CPT/ Inf (2015) 44) adopted in December 2015, available at http://www. cpt.coe.int/en/working-documents/cpt-inf-2015-44-eng.pdf (accessed 27 August 2021). The CPT Factsheet on Women in Prison (CPT/ $\operatorname{Inf}(2018) 5)$, adopted in 2018 affirms that they should 'enjoy access to a comprehensive programme of meaningful activities (work, training, education and sports) on an equal footing with men'. The Factsheet is available at https://www.coe.int/en/web/cpt/women-in-prison (accessed 27 August 2021)

16 Women's boxing was banned in Mexico in 1946 by presidential Decree. In 1941, the Brazilian President had banned women for participating in certain sports, including soccer (L'Hoeste et al. 2015).

17 Thus, specific changes have been made by the International Olympic Committee (IOC) to the Host City Contract with regard to human rights policy. The new version includes a section specifi-
}

international human rights monitoring bodies. The role played by the European Court of Human Rights (ECtHR) ${ }^{18}$ and the European Court of Justice (ECJ) (Parrish and Cattaneo 2018) is certainly worth mentioning. Both courts, each within its own jurisdiction, have already dealt with cases in which the compatibility of sporting rules with the European Convention for the Protection of Human Rights and Fundamental Freedoms (ECHR) ${ }^{19}$ and European Union (EU) law was at the heart of the matter. What is really relevant here is that there are a significant number of judgements adopted by both courts in which the decision on the application of certain sporting rules has been taken outside the sporting context. ${ }^{20}$ However, the role of UN has been more modest hitherto. In particular, and as far as is relevant here, the question of human rights violations in sports has been unsatisfactorily addressed by UN human rights adjudicatory mechanisms.

\section{Footnote 17 (Continued)}

cally designed to strengthen provisions protecting human rights and countering fraud and corruption related to the organization of the Olympic Games. Also, in May 2017, FIFA adopted its new human rights policy, based on the UN Guiding Principles on Business and Human Rights (available at https://www.fifa.com/about-fifa/whowe-are/news/fifa-publishes-landmark-human-rights-policy-2893311 (accessed 27 August 2021). Another example is the launching in July 2018, by the World Players Association, of the Universal Declaration of Players Rights, which includes player's right 'to pursue sport without limitation because of his or her race, color, birth, age, language, sexual orientation, gender, disability, pregnancy, religion, political or other opinion, responsibilities as a career, property or other status'. It is available at https://www.fifpro.org/media/md2efzpd/universaldeclaration-of-player-rights-english-version.pdf (accessed 27 August 2021).

${ }^{18}$ ECtHR (July 2021) Factsheet-Sport and the European Convention of Human Rights, available at https://www.echr.coe.int/Documents/ FS_Sport_ENG.pdf (accessed 27 August 2021).

19 Adopted on 4 November 1950, available at https://www.coe.int/ en/web/conventions/full-list? module $=$ treaty-detail $\&$ treatynum $=005$ (accessed 7 November 2021).

20 This was the case in the well-known Bosman case before the ECH (case C-415/93, Union royale belge des sociétés de football association ASBL and others $v$ Jean-Marc Bosman (EU:C:1995:463). Regarding the ECtHR, a significant number of judgements show that athletes have begun to trust the possibilities offered by the Strasbourg system in relation to the protection of their rights. Some of these cases will be referred to throughout this paper. The most recent cases, decided by the Court in May 2021, deal with sports and financial sanctions imposed on the applicants by the Turkish Football Federation in application of disciplinary sporting rules (Judgements of 18 May 2021, applications no. 48909/14, Sedat Doğan vs. Turkey, ECLI :CE:ECHR:2021:0518JUD004890914; no. 48924/16, Naki and Amed Sportif Faaliyetler Kulübü Derneği vs. Turkey, ECLI:CE:ECHR:2021 :0518JUD004892416; and no. 54540/15, Ibrahim Tokmak vs. Turkey, ECLI:CE:ECHR:2021:0518JUD005454016). In all three cases, the Court found violations of articles 6 (right to a fair hearing) and 10 (freedom of expression) of the ECHR. 
Indeed, UN human rights protection bodies' intervention in sports matters so far has been, to say the least, cautious. Academic studies have made visible human rights violations in the sporting domain (Donnelly 2008 and Morel 2012), have advocated for embedding human rights law in the sporting system (Schwab 2017), have paid attention to the question of the eventual role the ECtHR could play in this regard (Shinohara 2021), have underlined the importance of the UN Guiding Principles on Business and Human Rights $^{21}$ (Schwab 2018 and Wang 2020), and have proposed the creation of specialized human rights protection bodies (Anderson and Partington 2018; West 2019; Patel 2021). However, despite emphasizing the importance of IHRL, none has systematically analysed the chances for the UN system's human rights monitoring mechanisms to have a hand in the playing field. This article aims to fill this gap, while advocating for a more decisive action in this regard. The paper has been divided into three parts. The first one gives an overview of the limited role played up to date by UN bodies and mechanisms in promoting and protecting human rights in the sporting arena. The second part deals with the question of the determination of state responsibility for the commission of an internationally wrongful act under standards of due diligence in cases in which the fundamental rights of the athletes have been violated. Finally, some conclusions will be drawn.

\section{Sport as a human rights litigious matter: the limited experience of UN monitoring bodies}

\subsection{The UN 'human rights machinery' in a nutshell: how do treaty bodies work?}

The UN 'human rights machinery' is composed of a 'multiplicity of mechanisms working more or less towards the same goal': the promotion and protection of human rights worldwide (Alston and Mégret 2013, p. 1). For the purpose of our analysis, it is useful to distinguish between conventional or treaty-based and charter-based mechanisms.

\footnotetext{
21 The Guiding Principles were unanimously endorsed by the Human Rights Council the Guiding Principles in its Resolution 17/4 of 16 June 2011, available at https://www.undocs.org/en/A/HRC/RES/17/4 (accessed 27 August 2021).
}

The former are ten human rights treaty committees ${ }^{22}$ composed of independent experts who monitor compliance with the obligations imposed by the core international human rights treaties. ${ }^{23}$ States parties to these treaties assume the obligation to take all the necessary measures to ensure that everyone under their jurisdiction can enjoy the rights set out in them. As said, the role of the committees is to monitor compliance with this general obligation. These treaties establish specific mechanisms for this purpose. All committees conduct periodic reviews of states' compliance following a procedure based on the periodic submission by the state party of a report detailing all measures taken during the reporting period to comply with the obligations contained in the treaty. After reviewing the report, the committee in question issues its 'Concluding Observations': a set of recommendations aimed to enhance the implementation of those obligations. In addition to that, several of the committees may, under certain conditions set up in the relevant treaty or in the optional protocols, receive individual complaints, called communications, regarding actual or foreseen violations of the guaranteed human rights. ${ }^{24} \mathrm{Com}-$ plaint procedures can be brought only against a state that satisfies the following conditions. On the one hand, it must be a party to the treaty guarantying the rights which have allegedly been violated. On the other, the state party must have recognized the competence of the committee monitoring that treaty to receive and consider complaints from individuals. This means that in all cases, this mechanism is optional for the state party. That is, a state can be a party to a given treaty and not accept the competence of the monitoring committee to examine individual communications. Receiving inter-state communications are also possible for several committees. Accepting the committee's competence in this regard is also optional for the state. This is not the case for periodical reports, though. The competence of the committees is automatic in this case. Once the committee examines the admissibility and the merits of the case, it adopts a decision that represents and authoritative interpretation of the treaty. Committee's views are communicated

\footnotetext{
22 The Committee on the Elimination of Racial Discrimination (CERD), the Committee on Economic, Social and Cultural Rights (CESCR), the Human Rights Committee (HRC), the Committee on the Elimination of Discrimination against Women (CEDAW), the Committee against Torture (CAT), the Committee on the Rights of the Child (CRC), the Committee on Migrant Workers (CMW), the Subcommittee on Prevention of Torture (SPT), the Committee on the Rights of Persons with Disabilities (CRPD), and the Committee on Enforced Disappearances (CED).

${ }^{23}$ Strictly speaking, the Subcommittee on Prevention of Torture, established under the Optional Protocol to the Convention against Torture, monitors places of detention in states parties to it.

${ }^{24}$ In the case of the CMW, the individual complaint mechanism has not yet entered into force.
} 
both to the complainant ant to the state party and made public after the session at which they are adopted. It is well known, however, that, in general, 'effective implementation of decisions of international human rights bodies remains a significant challenge' (Sandoval et al. 2020, p. 71) and this is especially true regarding our ten treaty-based committees, since, at least formally, they lack binding nature. ${ }^{25} \mathrm{~A}$ final word has to be said on 'inquiries' and 'General Comments/ Recommendations'. Confidential inquiries, that may only be conducted with regard to states parties having recognized the competence of the committee in question in this regard, are initiated upon receiving reliable information concerning any serious, grave or systematic violations of the rights guaranteed by the treaties they monitor. General Comments or Recommendations are committees' interpretation of human rights treaty provisions, concrete topics or their methods of work. They are usually elaborated with the purpose of clarifying the extend of the conventional obligations imposed upon state parties and suggest ways of due implementation. They are also authoritative committee's views regarding the interpretations of concrete treaty provisions or a thematic issue.

As regards the charter-based mechanisms, in this paper, they will be identified with the so-called special procedures of the HRC. Being the most relevant intergovernmental UN body in charge of strengthening the promotion and protection of the human rights worldwide, it adopts resolutions concerning different questions related to that goal and establishes and supervises the work of a variety of subsidiary mechanisms. These include the Universal Periodic Review (UPR) process and the Special Procedures of the UN Human Rights Council. The UPR is a mechanism under which the human rights situation of all UN member states is reviewed every five years. The process is only operated since April 2008, starts with the peer-review of states' human rights situation, 'is followed by the implementation of the recommendations accepted and commitments made by states during the first stage, and culminates at the subsequent review with reports on the progress made' (Domínguez-Redondo 2012, p. 676). The Special Procedures may be thematic or geographic mandates. Mandates' holders are special rapporteurs, independent experts or working groups composed of five members who are appointed by the HRC. They are able to receive information about specific allegations of human rights breaches and send urgent appeals or letters of allegation.

It has to be taking into account that this universal human rights system coexists with the regional ones: the American,

\footnotetext{
25 It is not the purpose of this paper to elaborate on the legal nature of the pronouncements of these committees, a question that continues to be controversial. In particular, it is disputed whether they are binding on states parties or if they are simply recommendatory.
}

African and European systems. In these three cases, genuine permanent judicial bodies (the African Court of Human and Peoples' Rights, the Inter-American Court of HumanIACtHR - Rights and the ECtHR) monitor the compliance of States parties to the African Charter on Human and Peoples' Rights, ${ }^{26}$ the American Convention on Human Rights ${ }^{27}$ and the ECHR with their treaty obligations. Although it is not the purpose of this paper to delve into the peculiarities of each of them, the following should be noted. In all the cases mentioned, universal and regional, the victims have the possibility of lodging an application against the state they consider to be the responsible for one or more violations of the human rights contained in the corresponding instrument. While the same rights will often be protected by one or more universal treaties and by regional treaty instruments, the victims will not be able to seek simultaneous or successive protection from more than one mechanism for the same human rights violation. Considerations regarding res judicata and lis pendens will have to be taken into account (Reinisch 2004). An example of this is article 35.2.(b) of the ECHR, according to which an application that is substantially the same as a matter that has already been submitted to another procedure of international investigation or settlement and contains no relevant new information, will be declared inadmissible by the ECtHR. In another sense, it should also be noted that while regional human rights treaties clearly affirm the binding nature of these human rights court's judgements ${ }^{28}$ the legal nature of the committees' pronouncements remains controversial (Kanetake 2018).

Having briefly explained the mechanisms for the promotion and protection of human rights that operate in particular within the UN system, I will now analyse their work in relation to sporting issues. The purpose of this analysis is to reveal the absence of a systematic and relevant practice in this regard to date. An absence, on the other hand, practically ignored or at least overlooked in academia.

\subsection{Sporting issues within the work of the HRC}

\subsubsection{The HRC'political' pronouncements}

The HRC has repeatedly referred to sport in the context of the promotion of peace and development. Specifically, it has

\footnotetext{
${ }^{26}$ Adopted on 27 June 1981, available at https://www.achpr.org/legal instruments/detail?id=49 (accessed 7 November 2021).

27 Adopted on 22 November 1969, available at https://www.cidh.oas. org/basicos/english/basic3.american\%20convention.htm (accessed 7 November 2021)

${ }^{28}$ See art. 46.1 of the ECHR; art. 68.1 of the American Convention on Human Rights; and art. 30 of the Protocol to the African Charter on Human and Peoples' Rights on the Establishment of an African Court on Human and Peoples' Rights.
} 
periodically approved resolutions on promoting awareness, understanding and the application of the Universal Declaration of Human Rights through sport and the Olympic ideal. ${ }^{29}$ However, for the purpose of our study, HRC's pronouncements denouncing human rights violations suffered by athletes or that occur during major sporting events are more interesting. A recent example of these is the reaction to the Caster Semenya affair. ${ }^{30}$ This episode has drawn the attention of both the UN High Commissioner for Human Rights ${ }^{31}$ and of a group of Special Procedures of the HRC. ${ }^{32}$ Both pronouncements agree on the idea that World Athletics regulations are not compatible with international human rights norms and standards, including the rights of women with differences of sex development to equality and non-discrimination, to physical and mental health, and to physical and bodily integrity. These international rights are enshrined in international norms of a conventional or customary nature, binding on states. It is clear that, from a technical-legal point of view, these are not formally binding rules for the SGB's. ${ }^{33}$ The question that immediately arises is therefore how, through what mechanisms, mandate holders could contribute to their effective implementation by engaging state responsibility. In order to try to answer this question, I will now turn to the UPR and to the Special Procedures potential in this respect.

\subsubsection{The UPR: a possibility to make visible the commitment of states to the protection of human rights in the field of sport}

Human rights violations in the field of sport have remained largely absent from this process. It follows that either states are not aware of them or do not consider them sufficiently

\footnotetext{
${ }^{29}$ See for instance the Resolution adopted by the HRC on 22 June 2020 (A/HRC/RES/43/18), available at https://digitallibrary.un.org/ record/3875815? ln=es (accessed 27 August 2021).

30 As know, the South African athlete has decided to bring her case before the ECHR, which has been recently formally communicated to the Government of Switzerland (application no. 10934/21), https://t. co/o5ONNrALyu?amp $=1$ (accessed 27 August 2021). For an analysis of the case, see Krech (2021).

31 See the Report on Intersection of race and gender discrimination in sport Intersection of race and gender discrimination in sport, adopted on 15 June 2020, A/HRC/44/26.

${ }^{32}$ Letter of the Special Rapporteur on the right of everyone to the enjoyment of the highest attainable standard of physical and mental health; the Special Rapporteur on torture and other cruel, inhuman or degrading treatment or punishment; and the Working Group on the issue of discrimination against women in law and in practice: https:// www.ohchr.org/Documents/Issues/Health/Letter_IAAF_Sept2018.pdf (accessed 27 August 2021).

33 This does not prevent the mandate holders from urging in the letter, addressed to the President of World Athletics, the withdrawal of the eligibility regulations for the female classification
}

serious. And yet we know that they are. Therefore, UPR is a mechanism that should be better exploited to make these violations more visible. In this respect, a number of initiatives pushed by representatives of the civil society and aimed to encourage its use in this regard should be mentioned. ${ }^{34}$ The design of tools aiming to encourage states, National Human Rights Institutions and non-governmental organizations and associations to participate in the reporting process seems particularly useful. Even if the UPR is conceived as a state-driven process, civil society participation can certainly contribute to raise awareness around and make visible the violations of human rights in the sporting domain.

\subsubsection{Special procedures of the HRC}

Special procedures are a key part of the UN human rights protection system. Since its action does not depend on the ratification of a given international treaty, the consent of the state is not required. They carry out their work through a number of different procedures. First, it has to be taken into account that they can act on individual cases of alleged violations and/or concerns of structural nature by sending communications to states. They can also conduct thematic studies and convene expert consultations, as a way of contributing to the development of international human rights standards. Third, as in the case of Caster Semenya and other athletes with differences of sex development, they may engage in advocacy and raise public awareness. ${ }^{35}$ Finally, by providing advice for technical cooperation, they can help states and non-state actors to properly fulfil their obligations.

Special procedures mandate holders apply generally recognized international human rights protection standards. In their letter related to Caster Semenya, they consider that 'the eligibility criteria and the procedures for their implementation set forth in these regulations appear to contravene international human rights norms and standards including the right to equality and non-discrimination, the right to the highest attainable standard of physical and mental health, the right to physical and bodily integrity and the right to freedom from torture, and other cruel, inhuman or degrading treatment and harmful practices'. ${ }^{36}$ To support this assertion, they refer to the most relevant international legal instruments that guarantee these rights, on the one hand, and to previous pronouncements of other international human rights

\footnotetext{
${ }^{34}$ QueryInitiatives developed by the UNESCO Chair on Inclusive Physical Education, Sport, Recreation and Fitness (https://ifapa.net/ upr-35-information-meeting-on-sport-and-the-universal-periodicreview/) and the Centre for sport and human rights (http://www.sport andhumanrights.unescoittralee.com/index.php/7-universal-periodicreview-upr) are interesting examples (accessed 27 August 2021).

35 See supra note 31.

36 Ibídem, at p. 1.
} 
protection bodies, both charter and treaty based, on the other. Surprisingly, however, the letter does not contain references to the Yogyakarta Principles on the application of IHRL in relation to sexual orientation and gender identity. ${ }^{37}$ The Principles were adopted in 2007 by a group of experts and expanded on their tenth anniversary. ${ }^{38}$ The Yogyakarta Principles do not expressly refer to rights in sports. The YP+10 Principles do. First, additional obligations on states are set out in relation to Principle 2 (non-discrimination). Second, specific recommendations are addressed to sports organizations. They are asked to integrate the principles adopted in both 2007 and 2017, along with all relevant human rights norms and standards, into their policies and practices.

Pronouncements by the mandate's holders on human rights violations in sports are not common. Examples include the Report on girl's right to education adopted by the Special Rapporteur on the Right to Education in 2006. The Special Rapporteur considered the question of equality and non-discrimination in the field of sport, in this case between girls and boys, and underlined that 'boys usually have sufficient space to practice certain sports' while 'girls are not provided with similar space'. ${ }^{39}$

\subsection{The work of the UN treaty monitoring bodies}

\subsubsection{An overview on the practice so far...}

A preliminary conclusion can be announced. Questions related to the protection of human rights in the domain of sport have been marginalized in the UN treaty bodies' work. It should be noted at the outset that it has never been directly addressed by any of the committee's pronouncements. In particular, the almost complete silence of the committees in their General Recommendations/Comments is striking. ${ }^{40}$

\footnotetext{
37 Available at http://yogyakartaprinciples.org/wp-content/uploads/ 2016/08/principles_en.pdf (accessed 27 August 2021). On these Principles, see O'Flaherty and Fisher (2008).

38 The additional Yogyakarta Principles $(\mathrm{YP}+10)$ are available at http://yogyakartaprinciples.org/wp-content/uploads/2017/11/A5_ yogyakartaWEB-2.pdf (accessed 27 August 2021).

39 See paragraph 104 of the Report on girls' right to education, E/ CN.4/2006/45, 8 February 2006, available at https://digitallibrary.un. org/record/568795? $\mathrm{ln}=$ en (accessed 27 August 2021).

${ }^{40}$ Some marginal references can be found. See, for instance, General Recommendation No. 36 (2017) on the right of girls and women to education, adopted on 27 November 2017 (CEDAW C/GC/36), which refers to the scope of the obligation enshrined in art. $10(\mathrm{~g})$ of the Convention.According to CEDAW, this article provides that states parties are obliged to ensure that girls and women have the same opportunities as boys and men to actively participate in sports and physical education. The General Recommendation is available at tbinternet.ohchr.org/_layouts/15/treatybodyexternal/Download. asp ? symbolno $=\mathrm{CEDAW} / \mathrm{C} / \mathrm{GC} / 36 \& \mathrm{Lang}=\mathrm{en}$ (accessed 27 August 2021).
}

Of course, no General Recommendation/Comment has been adopted that focuses specifically on one or more of the human rights violations that occur in the field of sport. Second, the issue has been given scant consideration in the Concluding Observations as a consequence of the information periodically submitted by states in compliance with their obligations under human rights treaties whose compliance they monitor. Even so, we can cite some cases in which, exceptionally, the sporting issue emerges in the analysis of the relevant committee. Thus, the HRC has repeatedly referred to the persistence and importance of discrimination against women in the sport domain in certain countries and has affirmed that such discriminations breach article 3 of the International Covenant on Civil and Political Rights. ${ }^{41}$ The CEDAW Committee has also addressed this issue. For example, in the Concluding Observations to the seventh periodic report submitted by Italy, ${ }^{42}$ the Committee showed concern about the underrepresentation of women in sports federations and about the fact that women's sports competitions are allocated a significantly lower share of broadcasting time. ${ }^{43}$ But far from making concrete recommendations, the Committee confined itself to highlight the need of pursuing efforts to achieve substantive gender equality in sports, including through the use of temporary special measures. ${ }^{44}$ Examples from the $\mathrm{CRC}^{45}$ and the $\mathrm{CRPD}^{46}$ can also be cited.

Finally, the committees have also hardly addressed any alleged violations through individual communications. A thorough search in the committee's jurisprudence database $^{47}$ brings to light that athletes haven't resorted to this

\footnotetext{
$\overline{41}$ Concluding Observations regarding the second periodic report of the Islamic Republic of Iran (CCPR/C/28/Add.15) available at https:// tbinternet.ohchr.org/_layouts/15/treatybodyexternal/TBSearch.aspx? Lang=en\&TreatyID=8\&DocTypeID=5 (accessed 27 August 2021).

42 CEDAW/C/ITA/CO/7, 24 July 2017, available at https://tbinternet. ohchr.org/_layouts/15/treatybodyexternal/Download.aspx?symbolno= CEDAW\%2fC\%2fITA\%2fCO \%2f7\&Lang=en (accessed 27 August 2021).

${ }^{43}$ See paragraph 43 of the Concluding Observations.

44 Ibidem, at 44.

45 The Concluding Observations on the combined fifth and sixth periodic reports of Austria refer to an extremely important issue: sexual exploitation and abuses. It includes sports associations among the actors from which the state should collect data and asks Austria to provide detailed information in its next report, on reports, investigations, prosecutions and convictions: CRC/C/AUT/CO/5-6, 10 February 2020, available at https://tbinternet.ohchr.org/Treaties/CRC/ Shared\%20Documents/AUT/CRC_C_AUT_CO_5-6_41509_E.pdf (accessed 27 August 2021).

${ }^{46}$ As the Convention encompass a specific reference to sport in article 30, Concluding Observations systematically include a general reference to the state parties' obligation to effectively protect the right of persons with disabilities, especially children, to participate in sport.

${ }^{47}$ Most of the caselaw of the treaty bodies cited here can be found at the United Nations Treaty Body Jurisprudence Database available at https://juris.ohchr.org/ (accessed 27 August 2021).
} 
mechanism. As we will see below, a variety of combined reasons could explain this underutilization. Here too, however, I can refer to some examples.

In Hagan vs. Australia, ${ }^{48}$ the CERD concluded in 2003 that the use of an offending term in a football stadium grandstand and orally during the matches in honour to a famous sporting personality was in breach of the International Convention on the Elimination of All Forms of Racial Discrimination. ${ }^{49}$ In 2016, the CESCR declared inadmissible the communication submitted by a Colombian national on behalf of her minor son. He had received refugee status in 2009 in Ecuador, where the whole family had moved in 2002 to escape the violence in Colombia. The author of the communication claimed that her son was the victim of the violation by Ecuador of some of the rights enshrined in the Convention due to the refusal of the sporting authorities to register him due to his refugee status. The refusal prevented the minor from participating in certain competitions for which he had been selected. ${ }^{50}$ The CESCR decided that the communication is inadmissible under article 3, paragraph 1 , of the 2008 Optional Protocol establishing the competence of the committee to receive and consider communications since it concluded that domestic remedies had not been exhausted. Of course, a committee decision on the merits in a case where an SGB is at the origin of the alleged violation of the convention by the state would have been very interesting. The last example to be mentioned it's a much more recent one: the case of Yuliya Stepanova and Vitaly Stepanov vs. Russian Federation before the HRC. The victims are two of the whistle-blowers who revealed the Russian doping programme that ended up in the imposition by the IOC and WADA of sanctions on both athletes and Russian sports federations from 2016. They allege the violation of different rights protected by the ICCPR for which the respondent state would be responsible. ${ }^{51}$ In particular, those

\footnotetext{
48 Available at http://www.worldcourts.com/cerd/eng/decisions/2003. 03.20_Hagan_v_Australia.htm (accessed 27 August 2021).

49 The petitioner, Stephen Hagan, was an Australian national with origins in the Kooma and Kullilli Tribes of South Western Queensland. He alleged to be a victim of a violation by Australia of articles 2, 6 and 7 of the Convention. In 1960, the grandstand of an important sporting ground in Toowoomba, Queensland, where the author lived, was named the 'E.S. 'Nigger' Brown Stand', in honour of a wellknown sporting and civic personality, Mr. E.S. Brown. The offending term appeared on a large sign on the stand and was also repeated orally in public announcements relating to facilities at the ground and in match commentaries.

${ }^{50}$ A.M.B. vs. Ecuador, E/C.12/58/D/3/2014, 8 August 2016, available at https://tbinternet.ohchr.org/_layouts/15/treatybodyexternal/ SessionDetails1.aspx?SessionID=1059\&Lang=en (accessed 27 August 2021).

51 The Communication is available at: https://www.lls.edu/media/ loyolalawschool/academics/clinicsexperientiallearning/ihrc/Stepa novs\%20v\%20Russia\%20(3-1-2021)\%20for\%20distribution.pdf.
}

protected under articles 7 (prohibition of cruel, inhuman and degrading treatment and the prohibition of medical experiment without consent), 8.3.a) (right no to be subject to force labour or slavery), 17 (right not to be subject to arbitrary or unlawful interference with privacy and family or to unlawful attacks on honour and reputation), 19 (right to freedom of expression, and 23 (rights of families), in connection with article 2 (duty to respect and give effect to the Covenant).

\subsection{2 ... and some preliminary conclusions}

Sports-related human rights violations have so far been largely absent from the work of UN treaty-based human rights monitoring bodies. They have not addressed the issue either on their own initiative or at the request of potential victims. I will turn now to the possible reasons for this omission, on the one hand, and its consequences, on the other. Later in this paper, I will reflect on the possible advantages of a more decisive intervention of these mechanisms and the benefits this would have for the protection of the human rights of athletes and in the field of sport.

Let's start with the reasons behind UN human rights monitoring bodies' silence on sporting issues. First, it has to be taken into account that disputes arising in the field of sports usually demand a prompt response. As known, average span of professional athletes' careers is relatively short, which may prevent the answer of the committee from timely solving the problem. On the one hand, it has to be considered that exhaustion of domestic remedies is required before submitting a communication unless the application of such remedies is unreasonably prolonged or unlikely to bring effective relief. ${ }^{52}$ On the other, length of the procedures has to be taken into account. Although the duration of the procedure varies from committee to committee, 'for cases concluded in 2016, for example, it took the relevant committees, on average, three and a half years to reach their final Views' (Limon 2017, p. 25). Second, the sport movement shows a certain reluctance to let athletes to get their problems solved

\footnotetext{
${ }^{52}$ It is to be expected that on numerous occasions, athletes will seek to have the Court of Arbitration for Sport rule on the legality of certain sporting rules that restrict their rights. As known, this has been the case of Caster Semenya case and others affaires that have already been decided by the ECtHR. In such cases, the exhaustion of domestic remedies involves appealing the CAS award before the Swiss Federal Tribunal. The latter's decision opens the way to the ECtHR against Switzerland. It should be noted, in this regard, that 'while Switzerland has accepted a number of individual complaints mechanisms, it has not done so in respect of the complaint mechanism under two of the treaties most suited to address the issue at hand, namely, the ICCPR and ICESCR': Centre for Human Rights of the University of Pretoria (2020) The Caster Semenya case and options for further action within the international human rights law framework. https://www.chr.up.ac.za/caster-semenya-case\#_ftn7. Accessed 27 August 2021.
} 
by ordinary courts. ${ }^{53}$ Such an attitude is heavily influenced by the idea of specificity of sport and may even turn into incorporating the prohibition of accessing ordinary justice in the statutes of sporting federations. But it also works the other way round. As Nafziger has put it, the "historic reluctance' of domestic courts to adjudicate issues arising in the sports arena can be explained by the unfamiliarity with the subject matter and structure of sports (Nafziger 1992, p. 510). Finally, a risk of suffer reprisals from the sport movement is not an imaginary one. The case of the Belgium footballer, Jean-Marc Bosman, ${ }^{54}$ provides a useful example in this regard. His historical judicial success, that have been labelled as a hollow victory, 'alerted potential litigants to the costs of challenging the game structure' (Weatherill 2017, p. 99). Institutional condemnation of sportspeople who seek access to judicial remedies is one of the key elements explaining the success in the effective establishment and enforcement by the sport governing bodies (SGB's) of the lex sportiva (Schwab 2018, p. 218). However, UN committees could address human rights violations in sport even in the absence of victims' complaints. They could do so, for example, in the general comments or concluding observations that follow the periodic reports of states.

What are the consequences of this? Firstly, it makes the UN human rights protection system appear to be oblivious to human rights violations in the sporting environment. Of course, this feeds back into the idea that it is not an adequate or useful system in this sense, which leads to perpetuating its failure to be taken into account in strategies to defend the human rights of athletes. Secondly, they are therefore deprived of a possible means of defending their rights. Finally, states do not receive guidelines on how best to fulfil their obligation to protect athletes' rights, leading incomplete developments in IHRL regarding the protection of human rights in sports. The latter is a fundamental issue. It should not be lost sight of the fact that these mechanisms, like the ECtHR, are called upon to declare the responsibility of the state for non-compliance with obligations contained in international human rights treaties. This lurks serious questions related to when it can be considered that such responsibility should be declared, in particular when non-state actors are at the origin of the violations. Similarly, it is worth asking how a stronger contribution of the UN's international human rights protection bodies would lead to raising the standards of human rights protection in this area.

\footnotetext{
53 Although it refers to antidoping, the quote of the former vice-president of the International Amateur Athletics Association gathered by Foster is illustrative enough: 'Courts create a lot of problems for our anti-doping work, but we say we don't care in the least what they say. We have our rules, and they are supreme': Foster (2003), p. 1.

54 See supra, note 21.
}

It should be recalled, in any case, that the procedures and mechanisms referred to above are aimed at determining the responsibility of states for non-compliance with the obligations imposed by the IHRL. In the case of General Comments/Comments, the main purpose of the Committees is to clarify or outline the scope of those obligations. This forces us to address two different issues. On the one hand, and given that in most cases the origin of human rights violations in sports lies in norms or practices emanating from the sporting movement ${ }^{55}$, it must be considered under what circumstances the responsibility of the state could be declared in such cases. And, on the other hand, how this could contribute to the better protection of human rights in the field of sport. This will be discussed in the following section.

\section{International responsibility of states...}

\section{1 ...for the commission of an internationally wrongful act...}

A state breach of human rights law obligations in force for it, when the conduct can be attributed to it, constitutes an internationally wrongful act that may engage its responsibility according to the rules established by Articles on Responsibility of states for Internationally Wrongful Acts (ARSIWA) ${ }^{56}$ While the relationship between ARSIWA and human rights practice has been discussed at length, it is certain that state responsibility is declared through the conventional and extra-conventional mechanisms considered in the previous section. Both the ECtHR and the UN Committees, for example, will examine whether state conduct violates obligations under the human rights treaties they monitor. This objective constituent element of the internationally wrongful act requires an active or omissive conduct of that state which 'is not in conformity with what is required of it by that obligation, regardless of its origin or character' (ARWISA, art. 12).

It should be stressed that besides constituting a violation of a breach of an international obligation of the state, the conduct should be attributable to it under international law (ARWISA, art. 2). The question of attribution of responsibility to the state is problematic when human rights violations are committed by non-state actors. In these cases, the state is required to focus its efforts on preventing, protecting and

\footnotetext{
55 This is not the case of Yuliya Stepanova and Vitaly Stepanov vs. Russian Federation cited above (see supra, note 52), where there is prima facie evidence of sporting doping as a state policy.

56 International Law Commission (2001) available at https://legal. un.org/ilc/texts/instruments/english/commentaries/9_6_2001.pdf (accessed 27 August 2021).
} 
prosecuting with due diligence the human rights violations committed by non-state actors. Due diligence is here the key question. This means that a state 'may incur responsibility if it did not adequately prevent certain private misconduct subject to a due diligence standard' (Boon 2014, p. 363). The principle of due diligence is unavoidable in order to bridge responsibility gap. It is, however, an elastic and relative concept (Boon 2014, p. 367).

\section{2 ...under due diligence standards}

The private nature of national and international SGB's poses a key question: Why should the state be held responsible for the violations perpetrated by these private actors? As said, to answer this question, I have to refer to the principle of due diligence and its development within IHRL. This principle has gained centrality under IHRL helping to challenge the idea of human rights obligations considered to be aligned vertically, and not horizontally, and has already played an important role to assess state responsibility regarding violations of human rights that have a gender basis, i.e. domestic violence (Hasselbacher 2009) or trafficking in human beings (Waisman 2010). International human rights protection bodies and Courts have used this principle to implicate states in protecting individuals from human rights violations committed by non-state actors. ${ }^{57}$ The principle has also been explicitly enshrined in international human rights treaties. In this way, it has been considered as a specific source of obligations conventionally imposed. This is the case, for instance, of article 2 (f) of the CEDAW Convention ${ }^{58}$ when it comes to 'attacking the root causes of violence against women' (Holmaat 2009, p. 63).

Although in a different and multi-faceted sense, due diligence is 'at the heart of the United Nations Guiding Principles on Business and Human Rights, which establish the

\footnotetext{
57 It is commonplace to cite among the jurisprudential landmarks regarding state obligations stemming from the due diligence principle the pioneering judgement of the Inter-American Court of Human Rights in the case Velásquez Rodríguez vs. Honduras (29 July 1988), in which the Court held that 'an unlawful act violating human rights that is initially not directly attributable to a state, for example, because it is the work of a private individual or because the perpetrator of the violation has not been identified, may entail the international responsibility of the state, not for the act itself, but for lack of due diligence to prevent the violation or to address it in the terms required by the Convention' (paragraph 172). The judgement is available at https://www.corteidh.or.cr/cf/jurisprudencia2/index.cfm? lang $=$ en (accessed 27 August 2021).

58 Which imposes upon state parties to adopt all appropriate measures to eliminate discrimination against women by any person, organization or enterprise. Accordingly, states parties have to "prevent and deter private acts of discrimination, to investigate and negate the harmful consequences of private acts, and to provide for compensation or sanctions': Cook (1994), p. 166.
}

main parameters internationally for considering corporate responsibility for human rights violations' (Bonnitcha and McCorquodale 2018, p. 899). At the same time, as remembered by the authors, 'the concept of due diligence plays an important role in international human rights law in defining the extent of a state's obligations to prevent and respond to infringements of human rights by private actors within its territory or jurisdiction' (ibidem, p. 904) ${ }^{59}$ It should be clarified that this paper assumes due diligence is a secondary rule of general international law defining the 'general conditions under international law for states to be considered responsible for wrongful actions or omissions' (MackenzieGrey Scott 2021, p. 343-344).

An examination of the international practice revels that the state obligation of protecting individuals from human rights violations committed by other individuals has been traditionally linked to the personal security on aliens (Pisillo-Mazzeschi 1992, p. 22). Although in such cases the acts of the individuals could not the attributed to the state, its responsibility aroused from a different wrongful act: not prevent or punish the act performed by private individuals. Today, due diligence principle has gained its own central position under IHRL and imposes upon states the obligation of protecting all individuals under their jurisdiction from human rights violations committed by non-state actors. These include, private individuals, corporations or armed gangs (Hakimi 2010, p. 341). I would also include sport organizations on this list. In sum, states are obliged to exercise due diligence to prevent, investigate, prosecute and punish violations of human rights committed by non-state officials or private actors. In this context, the principle of due diligence 'relates to the question of whether the steps taken by the state are 'reasonable' or 'serious' when it comes to prevent those violations' (Chirwa 2004, p. 16). In other words, 'where the state takes reasonable measures to prevent and react to violations of human rights in private relations, the state will not be held responsible even when the outcome of those efforts is unsatisfactory' (ibidem).

The notion of due diligence is indeterminate and its role and nature within international law has been inconsistently characterized (McDonald 2019, p. 1043). In the context of IHRL, the assessment of whether the state has fulfilled the obligations deriving from it must be done on a case-by-case basis. At the same time, the notion of reasonableness refers to the idea that it would be disproportionate for the state to incur international responsibility for any human rights

\footnotetext{
59 The Guiding Principles have been someway endorsed by FIFA through the Report written by John G. Ruggie in 2016: For the Game. For the World. FIFA and Human Rights, available at https://www.hks. harvard.edu/sites/default/files/Ruggie_humanrightsFIFA_reportApri 12016.pdf (accessed 27 August 2021).
} 
violations committed by a non-state actor. Accordingly, it is worth noting that the international human rights protection bodies, which include the ECtHR and the IACHR, have embraced the view that the 'reasonableness' of the measures taken by the state is key in determining compliance by it with the duty to protect human rights on the basis of the principle of due diligence. As it has been said, reasonableness could be seen as 'the lens used to determine whether a state had exercised due diligence in a particular case involving wrongful conduct of a non-state actor' (MacKenzie Grey-Scott 2021, p. 361-362).

How to assess this reasonableness in the field of sport given the autonomy enjoyed by the sports authorities becomes a core issue. MacKenzie-Gray Scott has underlined that what has to be taken into account is whether it was feasible for the state to address the wrongful conduct of a non-state actor (MacKenzie Grey-Scott 2021, p. 362). If the state's nexus with the non-state actor is determinative in order to engage the liability of the former, it seems clear that the threshold for determining state responsibility will be quite high when the latter are SGB's. This is, in any case, an open question. Therefore, the pronouncements of the international human rights protection bodies can serve not only to define the extent of primary rules (i.e. the content of state's international obligations) the breach of which gives rise to responsibility regarding the protection of athlete's human rights, but also to assess the application of the principle of due diligence, as a secondary rule, in this area.

\section{Concluding remarks: rooting for a stronger commitment by human rights protection bodies to the protection of athletes' human rights}

From a legal perspective, sport is a riveting topic. As Prof. Rigaux brought to light in 1989, the economic exploitation of sport and entertainment has traditionally reached to skip state control. It is, he affirmed, 'a sacred cow that no government dare to reduce to the condition of a domesticated animal' (Rigaux 1989, p. 379). However, this trend is coming to an end. As far as this paper is concerned, it is possible to assert that there is a growing tendency to call for the application of international human rights protection standards in the field of sport. Still, the application of IHRL to the sport domain is turning out to be singularly challenging. This is mainly due to the autonomy that is enjoyed by SGB's in the enactment and application of their own lex sportiva. This paper assumes that embedding international human rights standards in the sporting domain would contribute not only to improving the protection of the rights of individual athletes, but also to strengthening the legitimacy of the sporting system as a whole.
In this context, this paper has sought to affirm that for the better achievement of those objectives, it would be desirable for the international human rights monitoring bodies to exercise their competences to address those violations. Regarding our topic, it seems clear that IHRL imposes concrete obligations upon states concerning the guarantee of human rights in the sporting arena. These obligations are contained in/have been deduced from both binding and nonbinding international instruments. In spite of these interesting developments, serious human rights violations persist at the sporting domain. When these violations derive from rules, measures or practices adopted or implemented by sports organizations, which have been considered non-state actors in this paper, state responsibility for the violation of human rights or athletes may arise from the principle of due diligence. However, since sport has been traditionally conceived as a self-contained regime, states may face serious difficulties in demonstrating that they have taken or could have taken reasonable and sufficient measures to prevent such violations. With such a scenario in mind, the eventual pronouncements of the UN international human rights protection bodies would help (i) to define the extent of primary rules imposed upon states and thus to assess the content of state's international obligations the breach of which gives rise to responsibility regarding the protection of athlete's human rights, and also (2) to assess the application of the principle of due diligence, which for the purposes of this paper has been considered a secondary rule.

The question that needed to be addressed next is through what mechanisms such intervention could take place. It has been reviewed in this paper what these mechanisms are and have also been shown that, in general, they have so far not been involved in human rights violations taking place in the sporting arena. Is it realistic to think that this situation can change? Regarding the intervention of UN treaty bodies through the individual complaint's procedure, I can conclude that possibility seems unlikely. The reasons have been explained above. However, since a stronger role of these mechanisms, both Charter and treaty based could make accountability for athletes' rights in the world of sport gather momentum, I have advocate for a more active role in this regard by way of general statements, General Recommendations and Concluding Observations. Also, the establishment of a special procedure specifically mandated for addressing the topic of human rights in sport should be considered by the HRC.

The mistrust, if not outright rejection, with which SGBs view the application of 'external' rules to sporting activity may be an unfounded fear. Far from ending up with an unconditional submission of the lex sportiva to the IHRL, from my perspective, the sport movement can rely on the international human rights protection bodies to be, when necessary, sensitive to the specificity of sport. The 
jurisprudence of the ECtHR is a case in point. It is known that IHRL does not conceive the enjoyment of human rights in absolute terms. It will be possible to restrict them in certain circumstances. And it is not unthinkable that international human rights protection mechanisms will be sensitive to certain 'sporting considerations'. As said, this has already been done by the ECtHR, which has decided that safeguarding the integrity of competitions and clean competitions in sports justifies the limitation of the right to private and family life, guaranteed by article 8 of the European Convention on Human Rights. In its judgement in FNASS and Others vs. France,${ }^{60}$ the ECtHR held that WADA's rules on the tracing of athletes for the purpose of out-of-competition doping controls do not violate this article. The Court took into account, in this regard, the need to protect the integrity of the competition and the equality of the participants in the competition. It held, in this regard, that such whereabout rules, admittedly very severe, are necessary in a democratic society in order to safeguard the rights and freedoms of others. ${ }^{61}$ Thus, in accordance with the second paragraph of article 8 , interference with the right to private and family life would be permissible.

What I would like to underline, by way of conclusion, is that the outcome of the intervention of international human rights protection bodies in sporting matters could therefore result in a dialogue between the lex sportiva and the IHRL that would promote mutual cross-fertilization. Such a dialogue could ultimately be useful for overcoming the mistrust that sports authorities seem to have in 'sports' being understood by the ordinary human rights protection system, on the one hand, and for enhancing SGB's reputation and legitimacy.

Acknowledgments An earlier version of this article was presented at the IJSL Special Issue on Remedy Workshop organized by the Centre for Sport and Human Rights that took place online on 2 and 3 June 2021. I would like to thank Antoine Duval and Daniela Heerdt and the rest participants for their pertinent and enriching comments. I would also like to thank the two anonymous reviewers for their careful reading of the paper and their kind and thoughtful comments.

Funding Open Access funding provided thanks to the CRUE-CSIC agreement with Springer Nature.

\footnotetext{
$\overline{60 \text { Judgement }}$ of 18 January 2018, applications no. 48141/11 and 77769/13, ECLI:CE:ECHR:2018:0118JUD004815111.

61 The 'others' are, in this case, the athletes participating in the competition, the group of amateur athletes and the general public. In this regard, the Court states that 'the use of doping substances in order to gain an advantage over other athletes unfairly eliminates competitors of the same level who do not have recourse to them is a dangerous incitement to amateur athletes, and in particular young athletes, to follow their example in order to improve their performance and deprives the spectators of the fair competition which they are entitled to expect' ( $c f r$. paragraph 166 of the judgement).
}

Open Access This article is licensed under a Creative Commons Attribution 4.0 International License, which permits use, sharing, adaptation, distribution and reproduction in any medium or format, as long as you give appropriate credit to the original author(s) and the source, provide a link to the Creative Commons licence, and indicate if changes were made. The images or other third party material in this article are included in the article's Creative Commons licence, unless indicated otherwise in a credit line to the material. If material is not included in the article's Creative Commons licence and your intended use is not permitted by statutory regulation or exceeds the permitted use, you will need to obtain permission directly from the copyright holder. To view a copy of this licence, visit http://creativecommons.org/licenses/by/4.0/.

\section{References}

Alston P, Mégret F (2013) Introduction: appraising the United Nations human rights regime. In: Alston P, Mégret F (eds) The United Nations and human rights: a critical appraisal. Oxford University Press, Oxford, pp 1-36

Anderson J, Partington N (2018) Duty of care in sport: time for a sports ombudsman? Int Sports Law Rev 1:3-10

Bonnitcha J, McCorquodale R (2017) The concept of 'Due Diligence' in the UN guiding principles on business and human rights. EJIL 28(3):899-919. https://doi.org/10.1093/ejil/chx042

Boon KE (2014) Are control tests fit for the future? The slippage problem in attribution doctrines. Melb J Int Law 15(2):330-377

Boxill J (2006) Football and Feminism. J Philos Sport 33(2):115-124. https://doi.org/10.1080/00948705.2006.9714696

Chirwa DM (2004) The doctrine of state responsibility as a potential means of holding private actors accountable for human rights. Melb J Int Law 5(1):1-37

Cook RJ (1994) State responsibility for violations of women's human rights. Harv Hum Rights J 7:125-175

Domínguez-Redondo E (2012) The universal periodic review: is there life beyond naming and shaming in human rights implementation? N Zeal Law Rev 4:673-706

Donnelly P (2008) Sport and Human Rights. Sport Soc 11(4):381-394. https://doi.org/10.1080/17430430802019326

Foster K (2003) Is there a global sports law? Entertainm Sports Law J 2(1):1-18

Hakimi M (2010) State bystander responsibility. EJIL 21(2):341-385

Hasselbacher L (2009) State obligations regarding domestic violence: the European court of human rights, due diligence, and international legal minimums of protection. Northwest J Int Hum Rights $8(2): 190-217$

Jarvei G (2021) Sport, soft power and cultural relations. J Glob Sport Manag. https://doi.org/10.1080/24704067.2021.1952093

Kanetake M (2018) UN human rights treaty monitoring bodies before domestic courts. Int Comp Law Quart 67(1):201-232

Kirchschlaeger PG (2016) Sports and human rights from an ethical perspective: the relevance of human rights for sports. In: Akrivopoulou $\mathrm{C}$ (ed) Defending human rights and democracy in the era of globalization. IGI Global, Pennsylvania, pp 337-360

Krech M (2021) 'Sport Sex' before the European court of human rights. https://www.asser.nl/SportsLaw/Blog/post/sport-sexbefore-the-european-court-of-human-rights-caster-semenya-vswitzerland-by. Accessed 27 Aug 2021

L'Hoeste H et al (2015) Sports and Nationalism in Latin/o America. Palgrave Macmillan, New York

Limon M (2017) Reform of the UN human rights petitions system. https://www.universal-rights.org/urg-policy-reports/reform-unhuman-rights-petitions-system-assessment-un-human-rightscommunications-procedures-proposals-single-integrated-system/. Accessed 27 Aug 2021 
MacKenzie Grey-Scott R (2021) Due diligence as a secondary rule of general international law. Leiden J Int Law 34(2):343-372. https:// doi.org/10.1017/S0922156521000030

McDonald N (2019) The role of due diligence in international law. Int Comp Law Quart 68(3):1041-1054. https://doi.org/10.1017/ S0020589319000344

Morel M (2012) Displaced in the name of sports: human rights law comes to the rescue. Hum Rts Int Legal Disc 6(2):229-258

Murray S (2013) Moving beyond the ping-pong table: sports diplomacy in the modern diplomatic environment. Public Dipl Mag 9:11-16

Nafziger JAR (1992) International sports law: a replay of characteristics and trends. AJIL 86(3):489-518. https://doi.org/10.2307/ 2203964

O'Flaherty M, Fisher J (2008) Sexual orientation, gender identity and international human rights law: contextualising the yogyakarta principles. Hum Rights Law Rev 8(2):207-248. https://doi.org/ 10.1093/hrlr/ngn009

Parrish R (2012) Lex sportiva and EU sports law. Eur Law Rev 37(6):716-733

Parrish R and Cattaneo A (2020) Sports law in the European Union. Kluwer Law International, Alphen aan den Rijn

Patel S (2021) Gaps in the protection of athletes gender rights in sport: a regulatory riddle. Int Sports Law J. https://doi.org/10.1007/ s40318-021-00182-2

Pisillo-Mazzeschi R (1992) The due diligence rules and the nature of the international responsibility of states. German Yearbook Int Law 35:9-51

Reinisch A (2004) The use and limits of Res Judicata and Lis Pendens as procedural tools to avoid conflicting dispute settlement outcomes. Law Prac Int Cts Tribunals 3:37-77

Rigaux F (1989) Les situations juridiques individuelles dans un système de relativité générale. Cours général de droit international privé. Recueil des Cours de l'Academie de Droit International de la Haye. Martinus Nijhoff, Dordrecht

Sandoval C et al (2020) Monitoring, cajoling and promoting dialogue: what role for supranational human rights bodies in the implementation of individual decisions? J Hum Rights Pract 12:71-100

Schwab B (2017) When we know better, we do better: embedding the human rights of players as a prerequisite to the legitimacy of lex sportiva and sport's justice System. Md J Int L 32:4-67

Schwab B (2018) Embedding the human rights of players in world sport. Int Sports Law J 17(3):214-232

Shahlaei F (2018) International responsibility of states and Victims of state-Sponsored Doping. Mich St Int Lett Rev 27(2):339-378

Shinohara J (2021) Physical and sexual abuse against young athlete in sport in light of article 8 of the European Convention on Human Rights (ECHR). Int Sports Law J. https://doi.org/10.1007/ s40318-021-00197-9

Waisman V (2010) Human trafficking: state obligations to protect victims' rights, the current framework and a new due diligence standard. Hast Int Comp Law Rev 33(2):385-430

Wang M (2020) The feasibility of implementing the United Nations Guiding Principles on Business and Human Rights in the megasporting events. Doctoral dissertation.

Weatherill S (2017) Principles and practice in EU sports law. Oxford University Press, Oxford

West D (2019) Revitalising a phantom regime: the adjudication of human rights complaints in sport. Int Sports Law J 19:2-17. https://doi.org/10.1007/s40318-019-00147-6

Publisher's Note Springer Nature remains neutral with regard to jurisdictional claims in published maps and institutional affiliations. 